\title{
Effect of hypoxia and Beraprost sodium on human pulmonary arterial smooth muscle cell proliferation: the role of p27kip I Maiko Kadowaki ${ }^{\dagger 1}$, Shiro Mizuno*†1, Yoshiki Demura1, Shingo Ameshima1, Isamu Miyamori ${ }^{1}$ and Takeshi Ishizaki ${ }^{\dagger 2}$
}

\begin{abstract}
Address: ${ }^{1}$ Third Department of Internal Medicine, University of Fukui, 23-3 Eiheiji-cho, Matsuoka, Yoshida-gun, Fukui, Japan and ${ }^{2}$ Department of Fundamental Nursing, University of Fukui, 23-3 Eiheiji-cho, Matsuoka, Yoshida-gun, Fukui, Japan

Email: Maiko Kadowaki - maik@u-fukui.ac.jp; Shiro Mizuno* - shirotan@qf6.so-net.ne.jp; Yoshiki Demura - demura@u-fukui.ac.jp; Shingo Ameshima - ame@u-fukui.ac.jp; Isamu Miyamori - miyamori@u-fukui.ac.jp; Takeshi Ishizaki - takeshi@u-fukui.ac.jp

* Corresponding author †Equal contributors
\end{abstract}

Published: I November 2007

Respiratory Research 2007, 8:77 doi:10.1 186/1465-9921-8-77

This article is available from: http://respiratory-research.com/content/8/I/77

(c) 2007 Kadowaki et al; licensee BioMed Central Ltd.

This is an Open Access article distributed under the terms of the Creative Commons Attribution License (http://creativecommons.org/licenses/by/2.0), which permits unrestricted use, distribution, and reproduction in any medium, provided the original work is properly cited.

\begin{abstract}
Background: Hypoxia induces the proliferation of pulmonary arterial smooth muscle cell (PASMC) in vivo and in vitro, and prostacyclin analogues are thought to inhibit the growth of PASMC. Previous studies suggest that P27kipl, a kind of cyclin-dependent kinase inhibitor, play an important role in the smooth muscle cell proliferation. However, the mechanism of hypoxia and the subcellular interactions between p27kipl and prostacyclin analogues in human pulmonary arterial smooth muscle cell (HPASMC) are not fully understood.
\end{abstract}

Methods: We investigated the role of P27kipl in the ability of Beraprost sodium (BPS; a stable prostacyclin analogue) to inhibit the proliferation of HPASMC during hypoxia. To clarify the biological effects of hypoxic air exposure and BPS on HPASMC, the cells were cultured in a hypoxic chamber under various oxygen concentrations $(0.1-21 \%)$. Thereafter, DNA synthesis was measured as bromodeoxyuridine (BrdU) incorporation, the cell cycle was analyzed by flow cytometry with propidium iodide staining. The p27kipl mRNA and protein expression and it's stability was measured by real-time RT-PCR and Western blotting. Further, we assessed the role of p27kipl in HPASMC proliferation using P27kipl gene knockdown using small interfering RNA (siRNA) transfection.

Results: Although severe hypoxia ( $0.1 \%$ oxygen) suppressed the proliferation of serum-stimulated HPASMC, moderate hypoxia ( $2 \%$ oxygen) enhanced proliferation in accordance with enhanced $\mathrm{p} 27 \mathrm{kipl}$ protein degradation, whereas BPS suppressed HPASMC proliferation under both hypoxic and normoxic conditions by suppressing P27kipl degradation with intracellular cAMP-elevation. The 8-bromo-cyclic adenosine monophosphate (8-BrcAMP), a cAMP analogue, had similar action as BPS in the regulation of p27kipl. Moderate hypoxia did not affect the stability of $\mathrm{P} 27 \mathrm{kipl}$ protein expression, but PDGF, known as major hypoxia-induced growth factors, significantly decreased p27kipl protein stability. We also demonstrated that BPS and 8-Br-cAMP suppressed HPASMC proliferation under both hypoxic and normoxic conditions by blocking P27kipl mRNA degradation. Furthermore, P27kipl gene silencing partially attenuated the effects of BPS and partially restored hypoxia-induced proliferation.

Conclusion: Our study suggests that moderate hypoxia induces HPASMC proliferation, which is partially dependent of $\mathrm{P} 27 \mathrm{kipl}$ down-regulation probably via the induction of growth factors such as PDGF, and BPS inhibits both the cell proliferation and p27kipl mRNA degradation through cAMP pathway. 


\section{Background}

Exposure to chronic hypoxia leads to pulmonary hypertension $(\mathrm{PH})$ associated with the structural remodeling of pulmonary vessels [1-3]. Many pulmonary disorders are associated with chronic hypoxia, accompanied by pulmonary hypertension and fatal right heart failure resulting from pulmonary vascular remodeling [4-6]. Prolonged exposure to hypoxia is associated with cellular and histological changes in vascular remodeling, and the key pathological findings of pulmonary vascular remodeling are increased wall thickening of pulmonary vessels and the muscularization of small arteries. Decreased ambient oxygen concentrations in laboratory animals cause similar pathological changes, including pulmonary smooth muscle hypertrophy and proliferation $[7,8]$. Furthermore, several studies in vitro have also shown that exposure to hypoxia stimulates pulmonary arterial smooth muscle cell (PASMC) proliferation, which might be a key component of pulmonary vascular remodeling [9-12].

Prostacyclin $\left(\mathrm{PGI}_{2}\right)$ is thought to improve exercise tolerance and survival in patients with either primary or secondary $\mathrm{PH}$ through its ability to inhibit the growth of PASMC [13-15]. TORAY Industries Inc. developed Beraprost sodium (BPS), which was the first chemically stable and orally active $\mathrm{PGI}_{2}$ analogue to increase intracellular cAMP levels via adenylate cyclase activation [16]. Since 1995, BPS has been used to treat PH and obstructive peripheral arterial disease $[17,18]$. The drug mimics the biological properties of $\mathrm{PGI}_{2}$, such as activating adenylate cyclase and increasing intracellular cAMP levels, through activation of the $\mathrm{PGI}_{2}$ receptor. Owing to its chemical characteristics, BPS is more stable and persistent than natural $\mathrm{PGI}_{2}$ and has higher affinity for the $\mathrm{PGI}_{2}$ receptor [19].

The proliferation of PASMC, which causes pulmonary vascular remodeling, requires the cells to enter the cell cycle. The most important molecular process for cell cycle progression is retinoblastoma protein phosphorylation by cyclin-dependent kinase (CDK)-cyclin complexes, and CDK activities are mainly regulated by CDK inhibitors [20] such as p27kip1. Other studies have found that the CDK inhibitor, p27kip1, plays an important role in the inhibition of CDK activity and in the proliferation of vascular smooth muscle cells [8,21-23]. On the other hand, $\mathrm{Li}$ et al. found that BPS suppresses systemic vascular smooth muscle proliferation through CAMP signaling via p27kip 1 expression [24]. On the contrary, cell cycle arrest at late $G_{1}$ is caused by $\mathrm{p} 27^{\mathrm{kip} 1}$ expression under severe hypoxia [25-27]. These results support the notion that the oxygen-dependent checkpoint of the cell cycle is controlled by p27kip 1 expression, and that cAMP signaling also interferes with the cell cycle and p2 $7^{\mathrm{kip} 1}$ expression. However, the precise mechanisms and interactions between the pathways activated by hypoxia, as well as the antiproliferative effects of $\mathrm{p} 27^{\mathrm{kip} 1}$ during exposure to BPS in pulmonary arterial smooth muscle cells remain uncertain. We aimed to clarify the inhibitory effect of BPS in cultured human pulmonary arterial smooth muscle cells (HPASMC), as well as interactions of the CDK inhibitor p27kip1. We assessed the effects of BPS and 8-bromo-cyclic adenosine monophosphate (8-Br-cAMP), a cAMP analogue, on cell proliferation and $\mathrm{p} 27^{\mathrm{kip} 1}$ expression, and examined the role of $\mathrm{p} 27^{\mathrm{kip} 1}$ in HPASMC proliferation using p27kip 1 gene silencing.

\section{Methods \\ Reagents}

We obtained reagents and materials from various sources as follows: Humedia SG medium, recombinant human EGF and FGF, gentamycin, streptomycin, and amphotericin B (Kurabo Ltd., Osaka, Japan); bromodeoxyuridine (BrdU) proliferation assay kits (Oncogene ${ }^{\mathrm{TM}}$, Cambridge, MA); low-pH cAMP ELISA kits (R\&D Systems, Inc., Minneapolis, MN); ECL detection system (Amersham, Buckinghamshire, UK); Moloney murine leukemia virus reverse transcriptase (Toyobo Co. Ltd., Osaka, Japan), Quantitech $^{\mathrm{TM}}$ SYBR Green PCR kits (Qiagen, Santa Clarita, CA); Lipofectamine 2000, 4 - 12\% Bis-Tris Nupage gels, and MES-SDS running buffer (Invitrogen, Carlsbad, CA); DC protein assay kit and polyvinylidene difluoride (PVDF) membranes (Bio-Rad Laboratories, Richmond, CA; rabbit anti-p27kip1 polyclonal antibody, mouse anti$\beta$-actin monoclonal antibody, horseradish peroxidaseconjugated goat anti-mouse and rabbit antibody, p27kip1 and control small interfering RNA (siRNA) (Santa Cruz Biotechnology Inc., Santa Cruz, CA) and BPS was a gift from Toray Industries Inc. (Tokyo, Japan). All other chemicals were purchased from Sigma (St. Louis, MO).

\section{Cell culture}

HPASMC supplied by Kurabo Ltd. (Osaka, Japan) were cultured in Humedia SG medium containing 5\% fetal bovine serum, with $50 \mu \mathrm{g} / \mathrm{ml}$ of gentamycin, $50 \mathrm{ng} / \mathrm{ml}$ of amphotericin B, $1 \mathrm{ng} / \mathrm{ml}$ of recombinant human EGF, and $1 \mathrm{ng} / \mathrm{ml}$ of recombinant human FGF. The cells were incubated in $75-\mathrm{cm}^{2}$ tissue culture flasks (Corning, NY, U.S.) in a cell-culture incubator $\left(37^{\circ} \mathrm{C}, 5 \% \mathrm{CO}_{2}\right.$, and $95 \%$ air) and used at the seventh passage after trypsinization in all experiments. Oxygen concentrations $(0.1 \% \sim 10 \%)$ were modified using $\mathrm{N}_{2}-\mathrm{CO}_{2}$ incubators (BNR-110M; Tabai ESPEC Corp., Tokyo, Japan; 10-0233, Ikemoto Rika Kogyo, Co., LTD., Tokyo, Japan).

\section{Incorporation of BrdU into HPASMC}

We incubated HPASMC $\left(6,000\right.$ cells $\left./ \mathrm{cm}^{2}\right)$ seeded in $96-$ well culture plates for $48 \mathrm{~h}$ in serum-free DMEM, then changed the medium to DMEM containing 10\% FBS and antibiotics. Thereafter, the cells were incubated for $24 \mathrm{~h}$ in 
various oxygen concentrations with or without $10 \mu \mathrm{M}$ BPS. We measured BrdU incorporation using BrdU proliferation assay kits according to the manufacturer's protocol. Briefly, the cells were labeled with $10 \mathrm{ng} / \mathrm{ml}$ of BrdU during the incubation, washed 3 times with cold PBS, fixed, air dried and incubated with mouse anti-BrdU monoclonal antibody (diluted 1:1,000). The antibody was aspirated, the cells were washed 3 times and then incubated with peroxidase goat anti-mouse $\operatorname{IgG}(1: 2,000)$ at room temperature for 30 minutes. The cells were washed 3 times, and $100 \mu \mathrm{M}$ substrate was added to each well and incubated for 10 minutes in darkness. Thereafter, we measured absorbance at dual-wave lengths of 450 to 540 nm.

\section{Cell cycle and DNA analyses}

We examined whether the cell cycle was influenced by the oxygen concentration using flow cytometry with propidium iodide staining. We incubated HPASMC (6,000 cells/ $\mathrm{cm}^{2}$ ) seeded in 6 -well culture plates for $48 \mathrm{~h}$ in serum free DMEM, then changed the medium to DMEM containing $10 \%$ FBS and antibiotics. The cells were further incubated for $24 \mathrm{~h}$ under normal or hypoxic conditions with or without $10 \mu \mathrm{M}$ BPS. The cells were harvested with trypsinEDTA and fixed using 70\% ethanol. The ethanol was removed and the cells were incubated in PBS containing RNase (172 $\mathrm{k}$ units $/ \mathrm{ml}$ ) at $37^{\circ} \mathrm{C}$ for 30 minutes, stained with propidium iodide $(50 \mu \mathrm{g} / \mathrm{ml})$ and suspended in PBS for 30 minutes on ice. DNA fluorescence was measured and flow cytometry proceeded using an EPICS XL (Beckman Coulter, CA).

\section{Assay of intracellular cAMP expression in HPASMC}

We incubated HPASMC $\left(6,000\right.$ cells $\left./ \mathrm{cm}^{2}\right)$ seeded in 24well culture plates for $48 \mathrm{~h}$ in serum-free DMEM then changed the medium to DMEM containing 10\% FBS. The plates were incubated for various periods under normal or hypoxic conditions in the presence of $10 \mu \mathrm{M}$ BPS. The medium was aspirated and adherent cells were solubilized with $200 \mu \mathrm{l}$ of $0.1 \mathrm{~N} \mathrm{HCl}$ and $0.1 \%$ Triton X. Thereafter, cAMP concentrations in the cell lysates were measured using a low-pH cAMP ELISA kit according to the manufacturer's protocol.

\section{Real-time $R$ T-PCR analysis of p2 $7^{\text {kipl }}$ using LightCycler ${ }^{\mathrm{TM}}$} We cultured HPASMC $\left(6,000\right.$ cells $\left./ \mathrm{cm}^{2}\right)$ seeded in $6-\mathrm{cm}$ dishes for $48 \mathrm{~h}$ in serum-free DMEM. The cells were washed twice with PBS, and then placed in DMEM containing 10\% FBS and antibiotics under normal or hypoxic oxygen concentrations for various periods with or without $10 \mu \mathrm{M}$ BPS or $1 \mathrm{mM}$ of 8 -Br-cAMP. The cells were then harvested by trypsinization, washed 3 times, and pelleted by centrifugation. Total cellular RNA was obtained by one acid guanidinium thiocyanate-phenol-chloroform extraction [28]. Reverse transcription proceeded using $0.5 \mu \mathrm{g}$ of total RNA and cDNA was synthesized using $200 \mathrm{U}$ of Moloney murine leukemia virus reverse transcriptase, 5 $\mu \mathrm{M}$ oligoDT, $1 \mathrm{mM}$ dNTPs, and $3 \mathrm{mM} \mathrm{Mg}^{2+}$ in a total volume of $20 \mu \mathrm{l}$. Annealing proceeded at room temperature for 5 minutes, extension at $44^{\circ} \mathrm{C}$ for 40 minutes, and chain termination at $99^{\circ} \mathrm{C}$ for 5 minutes.

We then performed PCR using the RT products and specific oligonucleotide primers for $\mathrm{p} 27^{\mathrm{kip} 1}$ and $\beta$-actin. The sequences of the forward and reverse primers for p27kip1 were 5'-GCCCTCCCCAGTCTCTCTTA-3' and 5'TCAAAACTCCCAAGCACCTC-3', respectively, and those of the forward and reverse primers for $\beta$-actin were $5^{\prime}$ GCAAGCAGGAGTATGACGAG-3' 5'-CAAATAAAGCCATGCCAATC-3', respectively. All PCR reactions proceeded using a LightCycler ${ }^{\mathrm{TM}}$ PCR system (Roche Diagnostics, Meylan, France) using DNA-binding SYBR green dye to detect PCR products. The cycling conditions were as follows: initial denaturation at $95^{\circ} \mathrm{C}$ for 15 minutes, 50 cycles of denaturation at $94^{\circ} \mathrm{C}$ for 15 seconds, annealing at $55^{\circ} \mathrm{C}$ for 15 seconds, and extension at $72^{\circ} \mathrm{C}$ for $15 \mathrm{sec}-$ onds. The $\beta$-actin gene served as the reference. The PCR products were isolated from the LightCycler ${ }^{\mathrm{TM}}$ glass capillaries, resolved by electrophoresis on 1.5\% agarose gels and confirmed by ethidium bromide (EB) staining. Each assay was repeated in 6 independent experiments.

\section{Western blot analysis}

We cultured HPASMC $\left(6,000\right.$ cells $\left./ \mathrm{cm}^{2}\right)$ seeded in $6-\mathrm{cm}$ dishes for $48 \mathrm{~h}$ in serum-free DMEM. The cells were washed twice with PBS, placed in DMEM containing 10\% FBS and antibiotics and then cultured under normal or hypoxic oxygen conditions for various periods with or without $10 \mu \mathrm{M}$ BPS or $1 \mathrm{mM}$ 8-Br-cAMP. The cells were then harvested and resuspended in protein lysis buffer (150 mM of NaCl, $20 \mathrm{mM}$ of Tris-HCl, 1\% NP-40, $10 \mathrm{mM}$ of EDTA, $10 \%$ glycerol, $1 \mathrm{mM}$ of PMSF, $10 \mu \mathrm{g} / \mathrm{ml}$ of aprotinin, $1 \mu \mathrm{g} / \mathrm{ml}$ of leupeptin, $1 \mu \mathrm{g} / \mathrm{ml}$ of pepstatin) and incubated for $30 \mathrm{~min}$ on ice. Cell lysates were clarified by centrifugation at $10,000 \mathrm{~g}$ for 15 minutes at $4{ }^{\circ} \mathrm{C}$, then the protein content in the supernatants was quantified using DC protein assay kits. Thereafter, $25 \mu \mathrm{g}$ of protein per lane was loaded onto $4-12 \%$ Bis-Tris Nupage gels with MES SDS running buffer, according to the manufacturer's protocol. The gels were transferred to PVDF membranes by electrophoresis at $100 \mathrm{~V}$ for $1 \mathrm{~h}$, then non-specific binding was blocked in PBS containing 0.2\% Tween 20 (PBS-T) and 5\% nonfat milk (blocking buffer) at room temperature for $1 \mathrm{~h}$. All antibodies were diluted in blocking buffer. The membrane was then probed with rabbit anti-p27kip1 polyclonal antibody (diluted $1: 1,000$ ) or mouse anti- $\beta$ actin monoclonal antibody (diluted 1:5000), and incubated for $1 \mathrm{~h}$ at room temperature. Membranes were washed with PBS-T and incubated with horseradish peroxidase-conjugated goat anti-rabbit or mouse IgG 
(diluted 1:2,000) for $2 \mathrm{~h}$ at room temperature. After washing with PBS-T, proteins were detected using the ECL system. Each assay was repeated in 4 independent experiments.

\section{Analysis of $p 27^{\mathrm{kipl}} \mathrm{mRNA}$ and protein stability}

We cultured HPASMC $\left(6,000\right.$ cells $\left./ \mathrm{cm}^{2}\right)$ seeded in $6-\mathrm{cm}$ dishes for $48 \mathrm{~h}$ in serum-free DMEM. The cells were washed twice with PBS, then placed in DMEM containing $10 \%$ FBS and cultured under normal or hypoxic conditions for the indicated periods in the presence of the transcription inhibitor actinomycin D (Act D) $(400 \mathrm{nM})$, or the protein synthesis inhibitor cycloheximide (CHX) (25 $\mu \mathrm{g} / \mathrm{ml})$, and with or without $10 \mu \mathrm{M}$ BPS, $1 \mathrm{mM} 8$-Br-cAMP or $25 \mathrm{ng} / \mathrm{ml}$ of platelet-derived growth factor (PDGF). The cells were then counted and mRNA and protein stability was examined per 50,000 cells incubated with Act D and CHX using RT-PCR and Western blotting, respectively. Each assay was repeated in 4 independent experiments.

\section{Transfection of siRNA in HPASMC}

We incubated HPASMC in 10-cm dishes in DMEM containing $10 \%$ FBS for $24 \mathrm{~h}$, until they reached about $60 \%$ confluence. After rinsing, the cells were incubated for $6 \mathrm{~h}$ with serum-free Opti-MEM medium, $5 \mu \mathrm{l} / \mathrm{ml}$ of Lipofectamine 2000, and $50 \mathrm{nM}$ control or p27kip 1 siRNA. The same amount of Opti-MEM medium containing 20\% FBS was added and the cells were incubated for a further for 16 h. At $24 \mathrm{~h}$ after transfection, the cells were cultured in serum-free DMEM for $48 \mathrm{~h}$, harvested and seeded $(6,000$ cells $/ \mathrm{cm}^{2}$ ) into $6-\mathrm{cm}$ dishes and 96-well culture plates, then incubated in DMEM supplemented with 10\% FBS and antibiotics for $24 \mathrm{~h}$ under normal or hypoxic conditions with or without $10 \mu \mathrm{M}$ BPS. We then measured BrdU incorporation into the transfected cells and confirmed target gene silencing by p27kip1 siRNA using Western blotting.

\section{Statistical analysis}

The results are expressed as means \pm SE. Statistical analysis was performed using ANOVA with Bonferroni correction for multiple comparisons. Comparisons were considered statistically significant at $\mathrm{p}<0.05$.

\section{Results}

\section{Effects of BPS on HPASMC proliferation during hypoxia}

Moderate hypoxia ( $2 \%$ oxygen) promoted, whereas severe hypoxia $(0.1 \%$ oxygen) suppressed DNA synthesis in serum-stimulated HPASMC (Fig. 1a). Under normal and moderately hypoxic conditions, BPS dose-dependently suppressed DNA synthesis starting at concentrations of 1 and $10 \mu \mathrm{M}$, respectively (Fig. 1b).

Cell cycle visualization by PI staining showed that about $95 \%$ of the cells cultured in serum-free DMEM was syn-
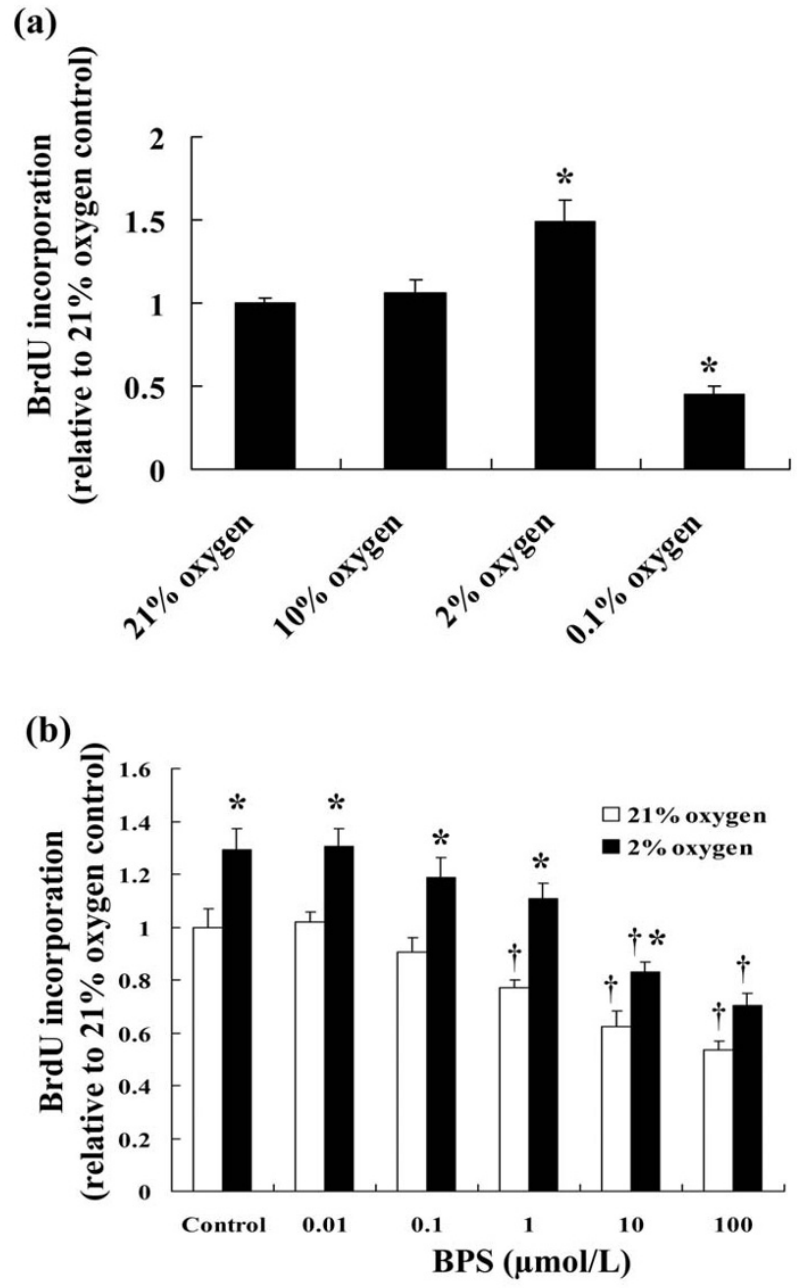

Figure I

Effects of hypoxia and BPS on BrdU incorporation in cultured HPASMC. Cultured HPASMC were exposed to various concentrations of oxygen and BPS in the presence of BrdU for 24 hours. (a) Severe hypoxia (0.1\% oxygen) suppressed, whereas moderate hypoxia ( $2 \%$ oxygen) significantly enhanced $\mathrm{BrdU}$ incorporation. $* \mathrm{P}<0.05$ versus $21 \%$ oxygen. (b) $\mathrm{BrdU}$ incorporation was dose-dependently suppressed by BPS under both normoxic and hypoxic conditions. Data are expressed as means $\pm S E(n=6)$. Open bars, $21 \%$ oxygen; solid bars, $2 \%$ oxygen. $* P<0.05$ versus $21 \%$ oxygen control; tP $<0.05$ versus without BPS.

chronized at the $G_{0 / 1}$ phase and that the cell cycle was arrested (quiescent state). Moderate hypoxia significantly promoted cell cycle progression and forced the cells to enter the $S$ and $G_{2} / M$ phases compared with the control under normal oxygen conditions and BPS significantly suppressed the cell cycle progression of cells that were serum-stimulated under hypoxic conditions (Fig. 2). 

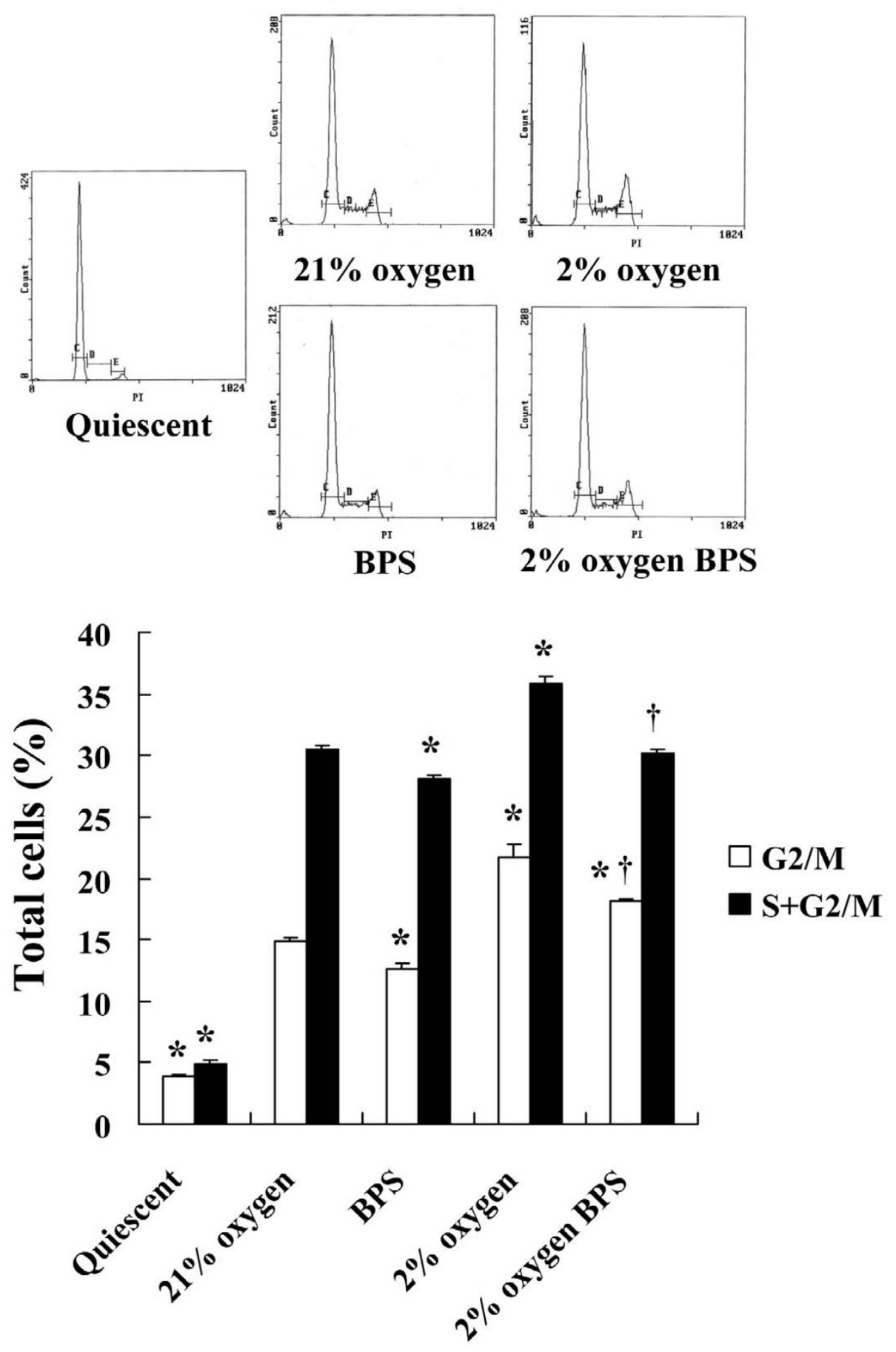

Figure 2

Cell cycle analysis of HPASMC exposed to hypoxia and BPS. Cultured HPASMC were exposed to $21 \%$ and $2 \%$ oxygen with or without $10 \mu \mathrm{M}$ BPS for 24 hours. Cells were harvested and DNA fragmentation was analyzed using flow cytometry and propidium iodide staining. Area definitions on DNA histograms: $C, G_{0 / 1}$ phase; $D, S$ phase; $E, G_{2} / M$ phase. Moderate hypoxia ( $2 \%$ oxygen) increased, whereas BPS significantly decreased ratios of $S$ plus $G_{2} / M$ and $G_{2} / M$ phases. Histograms are representative and bar graph shows data expressed as means $\pm S E(n=4)$. Open bars, ratios of $G_{2} / M$ phases; solid bars, ratios of $S$ plus $\mathrm{G}_{2} / \mathrm{M}$ phases. ${ }^{\mathrm{P}} \mathrm{P}<0.05$ versus $21 \%$ oxygen control; $\mathrm{tP}<0.05$ versus $2 \%$ oxygen without $B P S$. 


\section{Effects of BPS on CAMP production during hypoxia} Intracellular cAMP production was elevated by $10 \mu \mathrm{M}$ BPS from $15 \mathrm{~min}$ until $24 \mathrm{~h}$. Intracellular cAMP production did not significantly differ between ambient and hypoxic oxygen concentrations (Fig. 3).

\section{Effects of BPS and 8-Br-cAMPon p27kipl mRNA expression during hypoxia}

After incubation in serum-depleted medium (quiescent state), p27kip1 mRNA expression was obviously up-regulated, and decreased by $24 \mathrm{~h}$ of serum stimulation. On the other hand, BPS and 8-Br-cAMP significantly attenuated the suppression induced by $24 \mathrm{~h}$ of serum stimulation. However, p27kip1 mRNA expression did not significantly differ between normoxia and moderate hypoxia (Fig. 4a).

To confirm the effect of BPS and hypoxia on p27kip1 mRNA expression, we assessed p27kip1 mRNA stability

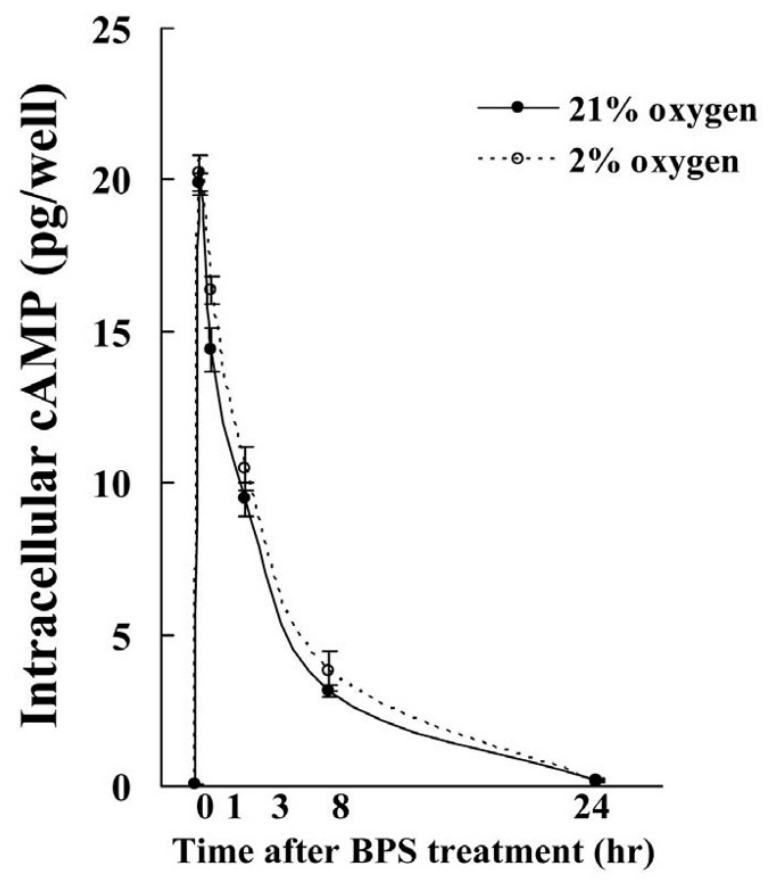

Figure 3

Effects of BPS on intracellular CAMP production during hypoxia. Cultured HPASMC were exposed to $21 \%$ or $2 \%$ oxygen in the presence or absence of $10 \mu \mathrm{M}$ of BPS for indicated periods. Concentrations of CAMP in cell lysates were measured using low-pH cAMP ELISA kits. Although BPS significantly induced cAMP expression, intracellular CAMP expression did not significantly differ between the indicated oxygen concentrations. Line with solid circles, $21 \%$ oxygen; dotted line with open circles, $2 \%$ oxygen. Data are expressed as means $\pm \operatorname{SE}(n=6)$.

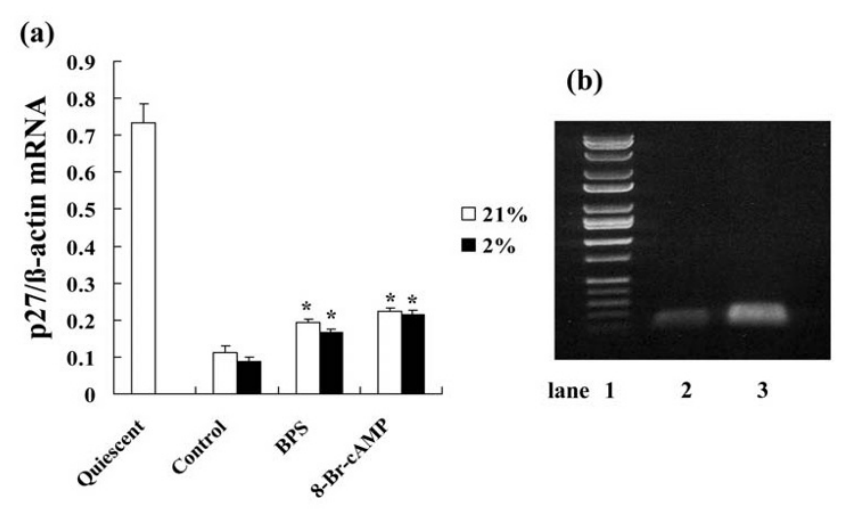

Figure 4

Effects of BPS and 8-Br-cAMPon p27kipl mRNA expression during hypoxia. Cultured HPASMC were exposed to $21 \%$ or $2 \%$ oxygen concentrations with or without $10 \mu \mathrm{M}$ of BPS or I mM 8-Br-cAMP for indicated periods. Expression of p27kipl mRNA was measured using Real-time RT-PCR using LightCycler ${ }^{\mathrm{TM}}$. (a) BPS suppressed p27kip I mRNA reduction under both normoxic and hypoxic conditions. Expression of p27kipl mRNA between normoxic and hypoxic conditions did not significantly change. Graph shows ratio of $277^{\mathrm{kipl}}$ to $\beta$-actin mRNA expression. Open and solid bars, $21 \%$ and $2 \%$ oxygen, respectively. Data are expressed as means $\pm S E(n=6)$. *P $<0.05$ versus control. (b) Agarose gel electrophoresis with EB staining revealed single amplification of predicted PCR products (lane I, DNA molecular weight markers; lane 2, p27kipl; I09 bp; lane 3, $\beta$-actin I44 bp).

using Act D. Both BPS and 8-Br-cAMP significantly suppressed p2 $7^{\mathrm{kip} 1} \mathrm{mRNA}$ degradation in cells incubated with Act D under both normoxic and moderately hypoxic conditions. Although moderate hypoxia did not change p27kip1 mRNA expression, mRNA stability was slightly decreased under moderate hypoxia (Fig. 5).

The PCR products were analyzed by agarose gel electrophoresis followed by EB staining, which revealed discrete amplification products of the predicted size (Fig. 4b).

\section{Effects of BPS and 8-Br-cAMP on p2 $^{2 \mathrm{kipl}}$ protein expression during hypoxia}

A large amount of $\mathrm{p} 27^{\mathrm{kip} 1}$ protein was expressed during the quiescent state after serum depletion. Serum stimulation significantly decreased p27kip 1 protein expression, which was significantly augmented by moderate hypoxia for $24 \mathrm{~h}$. In contrast, BPS significantly blocked the reduction in $\mathrm{p} 27^{\mathrm{kip} 1}$ protein. Incubation with $1 \mathrm{mM} 8$-Br-cAMP and BPS similarly affected p27kip1 protein expression under both normoxic and hypoxic conditions (Fig. 6).

To further understand role of hypoxia and BPS on p27kip1 protein expression, we analyzed the stability of p27kip1 

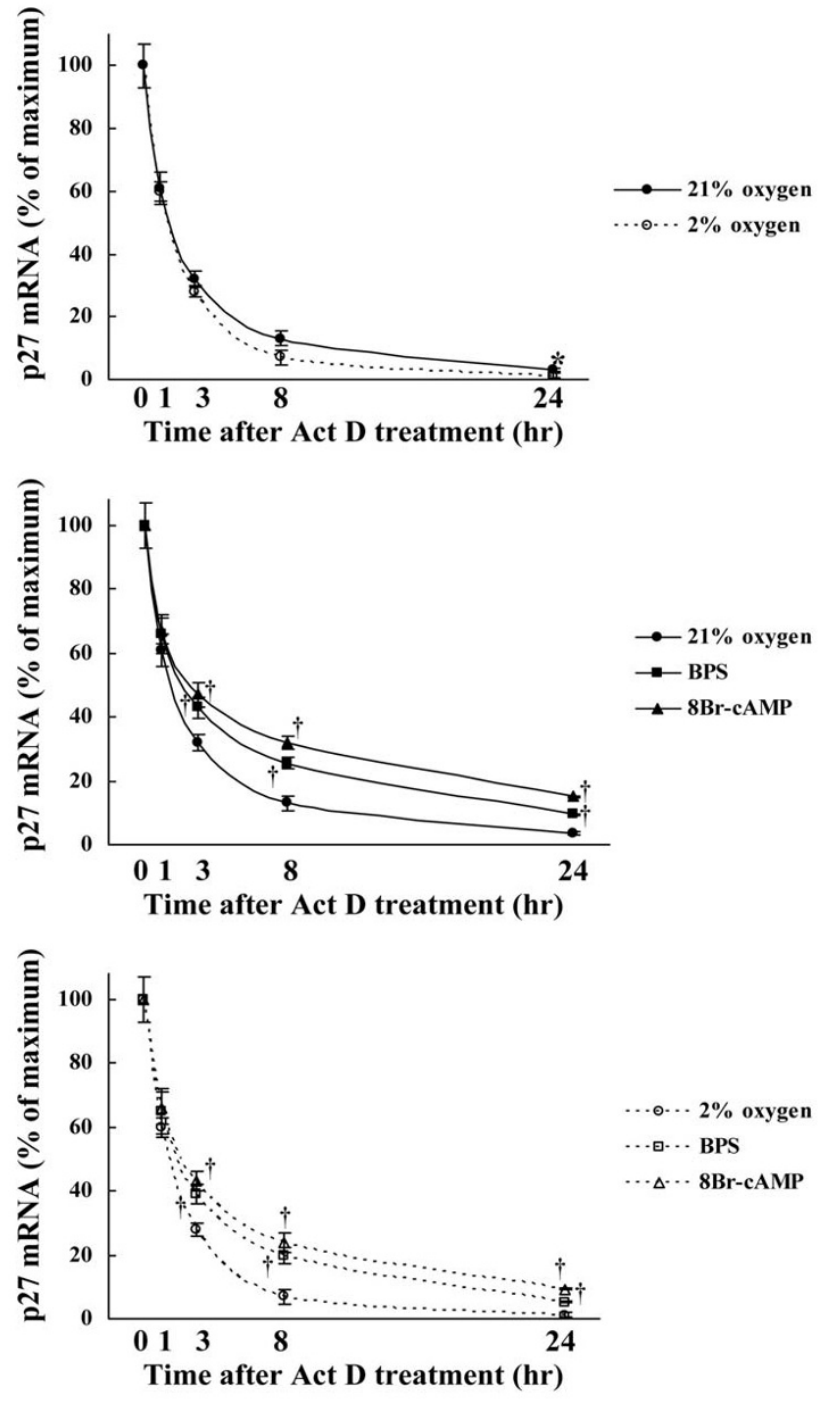

\section{Figure 5}

Effect of BPS and 8-Br-cAMP on p27kipl mRNA stability during hypoxia. Cultured HPASMC were exposed to $21 \%$ or $2 \%$ oxygen concentrations with or without $10 \mu \mathrm{M}$ of BPS or I mM 8-Br-cAMP for indicated periods. The p27kip I mRNA stability was measured after adding $400 \mathrm{nM}$ of Act D using Real-time RT-PCR using LightCycler ${ }^{\mathrm{TM}}$. Degradation of P27kipl mRNA was significantly suppressed by BPS and 8-BrCAMP under both normoxic and moderately hypoxic conditions, and mRNA stability was slightly decreased by moderate hypoxia. Graphs show \% maximal p27kip I mRNA expression. Line with solid circles, $21 \%$ oxygen; dotted line with open circles, $2 \%$ oxygen; line with solid squares, $21 \%$ oxygen and BPS; line with solid triangles, $21 \%$ oxygen and $8-$ $\mathrm{Br}$-cAMP; dotted line with open squares, $2 \%$ oxygen and BPS; dotted line with open triangle, $2 \%$ oxygen and $8-\mathrm{Br}$-cAMP. Data are expressed as means \pm SE $(n=6)$. $* P<0.05$ versus $21 \%$ oxygen. $\mathrm{tP}<0.05$ versus oxygen controls.
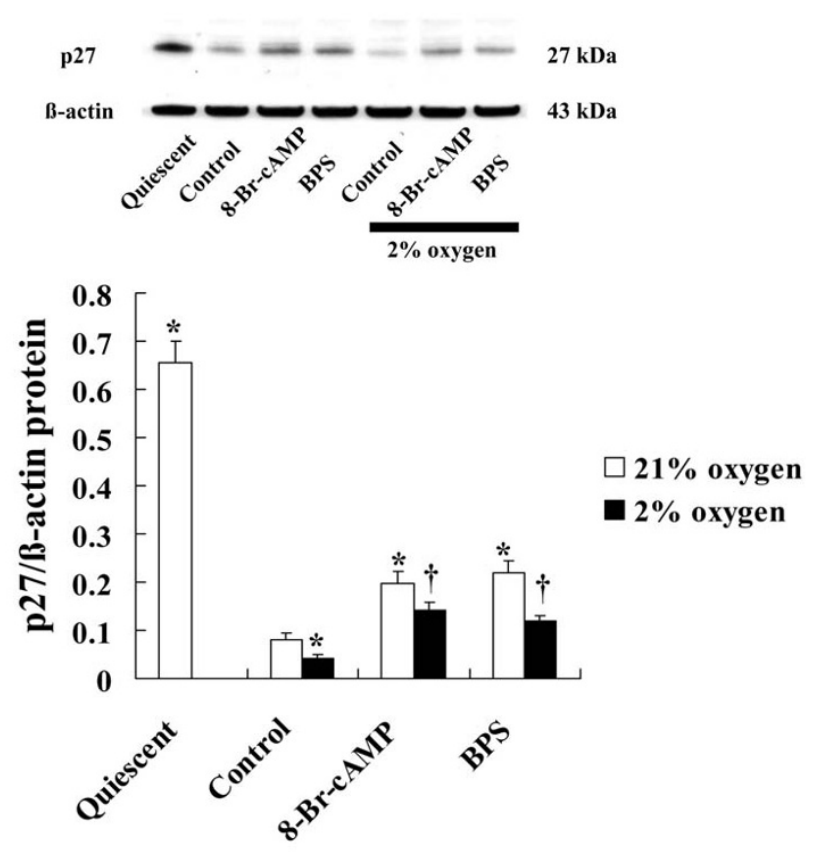

Figure 6

Effects of BPS and 8-Br-cAMP on p27kipl protein expression during hypoxia. Cultured HPASMC were exposed to $21 \%$ and $2 \%$ oxygen with or without $1 \mathrm{mM}$ of 8 Br-cAMP or $10 \mu \mathrm{M}$ of BPS for 24 hours, and then Western blotted. Hypoxia decreased $\mathrm{p} 27 \mathrm{kipl}$ protein expression. BPS and $8-\mathrm{Br}$-cAMP each significantly increased p27kipl protein expression under both normoxia and hypoxia. Photomicrographs are representative of 4 similar experiments, and bar graphs show density ratios of $227 \mathrm{kipl}$ protein versus those of $\beta$-actin bands. Open and solid bars, $21 \%$ and $2 \%$ oxygen, respectively. Data are expressed as means $\pm S E(n=4)$. $* P<$ 0.05 versus $21 \%$ oxygen control. $\nmid P<0.05$ versus $2 \%$ oxygen.

protein using CHX. Neither BPS nor 8-Br-cAMP altered p27kip1 protein stability. Moderate hypoxia did not affect the stability of p27kip1 expression, but decreased the amount of p27kip1 protein. We examined the effect of hypoxia-induced growth factors using PDGF, a key growth factor induced by hypoxia, on $\mathrm{p} 27^{\mathrm{kip} 1}$ protein stability. Under normoxic conditions, $25 \mathrm{ng} / \mathrm{ml}$ of PDGF significantly decreased $\mathrm{p} 27^{\mathrm{kip} 1}$ protein stability compared with the control (Fig. 7).

\section{Effects of hypoxia and BPS on p27kipl knockdown HPASMC proliferation}

To understand the role of p27kip1 in terms of the inhibitory effect of BPS on cell proliferation, we examined DNA synthesis in HPASMC transfected with p27kip1 siRNA under hypoxia in the presence of $10 \mu \mathrm{M}$ BPS. Western blots showed that transfection with p2 $7^{\mathrm{kip} 1}$ siRNA significantly suppressed p $27^{\mathrm{kip} 1}$ protein expression. Transfection 

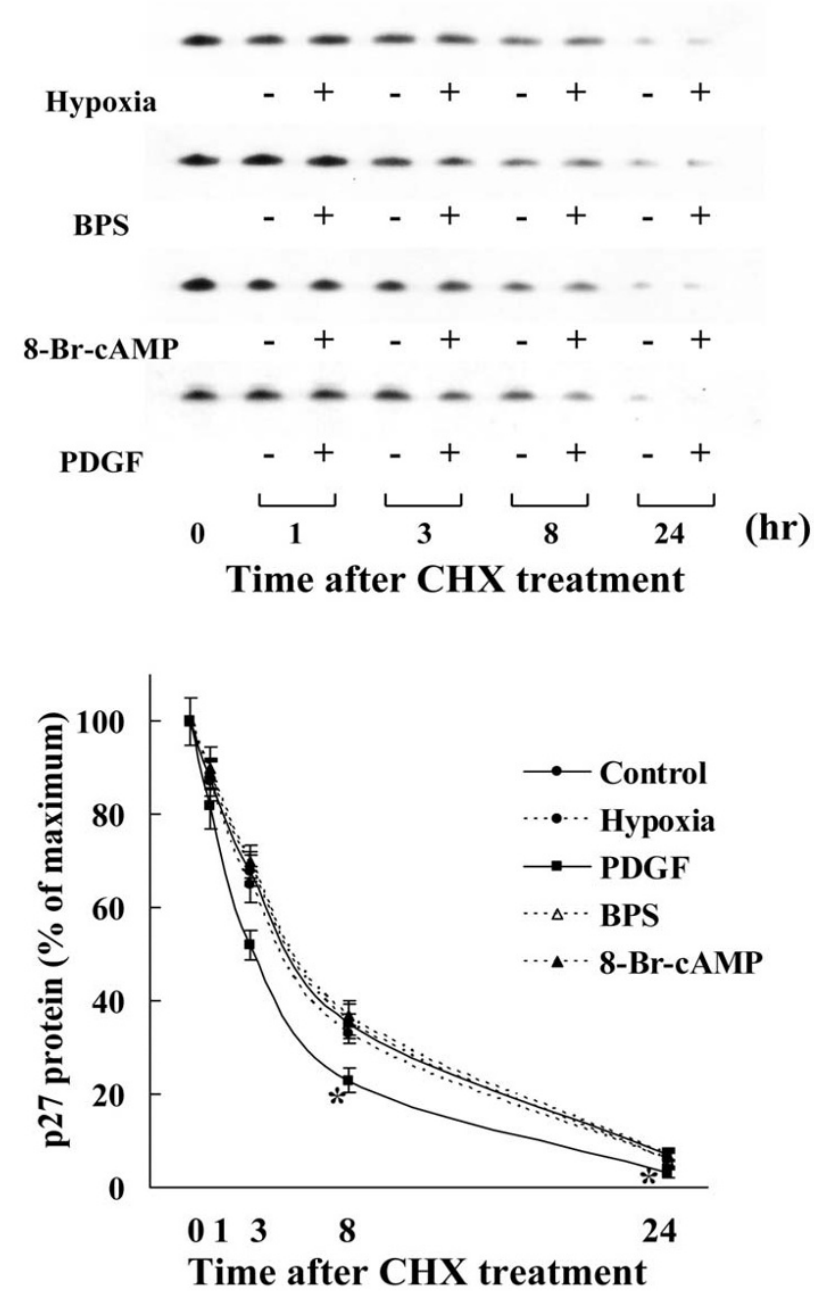

Figure 7

Effects of BPS, 8-Br-cAMP, hypoxia, and PDGF on p27kip I protein stability. Cultured HPASMC were exposed to $21 \%$ or $2 \%$ oxygen with or without $10 \mu \mathrm{M}$ BPS, I $\mathrm{mM} 8-\mathrm{Br}$-cAMP, or $25 \mathrm{ng} / \mathrm{ml}$ PDGF and $25 \mu \mathrm{g} / \mathrm{ml}$ of $\mathrm{CHX}$ for indicated periods and Western blotted. Degradation of p27kipl expression did not significantly change among cells exposed to hypoxia, BPS, or 8-Br-cAMP. PDGF promoted degradation of $227^{\mathrm{kipl}}$ protein expression. Graphs show \% of maximal p27kipl protein expression. Line with solid circles, $21 \%$ oxygen (control); dotted line with open circles, $2 \%$ oxygen (hypoxia); line with solid squares, PDGF; dotted line with open triangles, BPS; dotted line with solid triangles, 8-Br-

CAMP. Data are expressed as means \pm SE $(n=4)$. $* P<0.05$ versus $21 \%$ oxygen.

with control siRNA, which has a random sequence, did not affect $\mathrm{p} 27^{\mathrm{kip} 1}$ protein expression. We found that BPS increased $\mathrm{p} 27^{\mathrm{kip} 1}$ protein expression and significantly suppressed DNA synthesis in cells transfected with control siRNA. In contrast, transfection with p27kip1 siRNA signif-
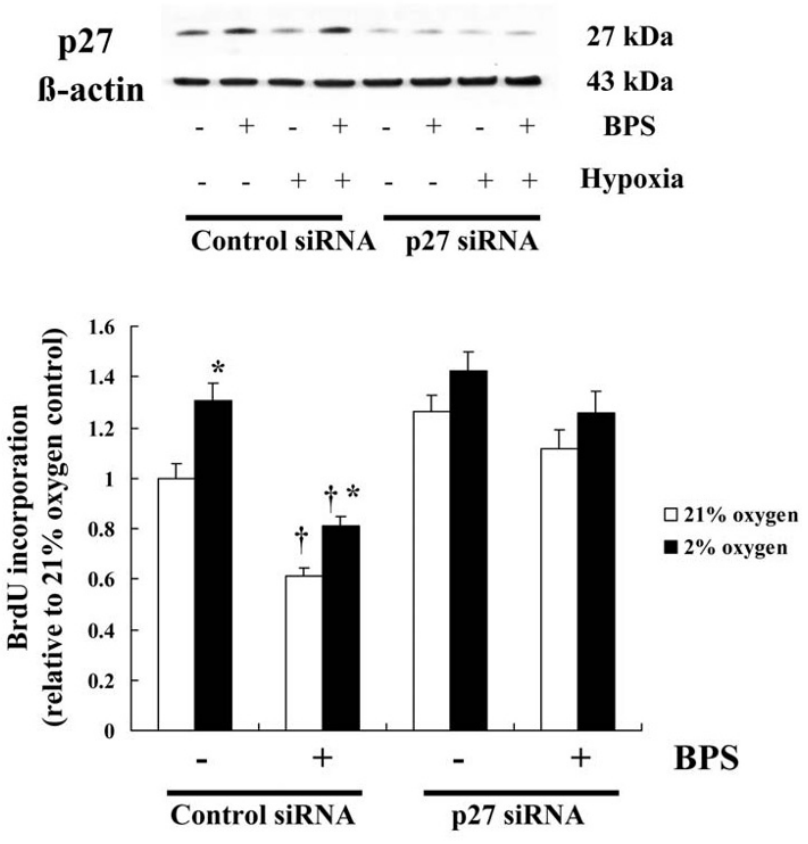

Figure 8

Effects of hypoxia and BPS on BrdU incorporation in cells transfected with p27kipl siRNA. HPASMC were transfected with control or p27kip I siRNA, then exposed to $21 \%$ and $2 \%$ oxygen with or without $10 \mu \mathrm{M}$ BPS for $24 \mathrm{~h}$. Western blot analysis showed that $\mathrm{P} 27^{\mathrm{kip}} \mathrm{I}$ protein expression in cells transfected with p27kipl siRNA was significantly suppressed under all conditions. Photomicrographs are representative of 4 similar experiments. Transfection with p27kip I siRNA significantly prevented BPS-induced inhibition of DNA synthesis. Bar graphs show BrdU incorporation relative to $21 \%$ oxygen control. Open and solid bars, $21 \%$ and $2 \%$ oxygen, respectively. Data are expressed as means \pm SE $(n=6)$. $* \mathrm{P}<0.05$ versus with $21 \%$ oxygen; $\uparrow \mathrm{P}<0.05$ versus without BPS.

icantly decreased p27kip1 protein expression and prevented the BPS-induced inhibition of DNA synthesis. In addition, moderate hypoxia significantly promoted DNA synthesis and reduced p $27^{\mathrm{kip} 1}$ protein expression in the control cells, but not in the cells transfected with p27kip1 siRNA (Fig. 8).

\section{Discussion}

We showed here that moderate hypoxia (2\% oxygen) enhanced the proliferation of serum-stimulated HPASMC in accordance with promoted $\mathrm{p} 27^{\mathrm{kip} 1}$ protein degradation, probably via the induction of growth factors such as PDGF. We also demonstrated that BPS suppressed HPASMC proliferation under both hypoxic and normoxic conditions by blocking p27kip1 mRNA degradation through an increase in intracellular cAMP. In addition, we 
confirmed using $\mathrm{p} 27^{\mathrm{kip} 1}$ gene silencing that $\mathrm{p} 27^{\mathrm{kip} 1}$ regulation in fact reflects HPASMC proliferation.

Increased levels of growth factors derived from the accumulation of hypoxia-inducible factor $1 \alpha$ (HIF-1 $\alpha$ ) are thought to regulate PASMC proliferation under hypoxic conditions since a partial HIF- $1 \alpha$ deficiency decreases muscularizartion of pulmonary arterioles in animals exposed to chronic hypoxia [7]. Although HIF-1 $\alpha$ regulates various transcriptional genes for angiogenic factors, severe hypoxia and iron depletion induce cell growth arrest. Our finding that severe hypoxia ( $0.1 \%$ oxygen) suppressed nucleotide synthesis is in line with those of others who incubated several tumor cell lines under hypoxic conditions or with iron chelators $[25,29]$. In contrast to severe hypoxia, other studies have indicated that moderate hypoxia ( $1-5 \%$ oxygen) enhances the proliferation of rat and bovine PASMC, airway-smooth muscle cells, lung fibroblasts and mesangial cells [30-33]. Our findings that DNA synthesis was increased during moderate hypoxia, and that the HPASMC cell cycle progresses more quickly under hypoxic than normoxic conditions were also compatible with previous findings.

The suppressive effect of hypoxia on p27kip1 expression has been demonstrated in mice with pulmonary hypertension induced by hypoxia [8]. However, the expression of p27kip1, which blocks the cell cycle at the $\mathrm{G}_{0 / 1}$ phase, is regulated via several mechanisms including transcription, protein degradation and translation [34-36]. The data presented here indicated that hypoxia minimally promoted p27kip 1 mRNA degradation. Our data also suggested that the hypoxia-induced down-regulation of $\mathrm{p} 27^{\mathrm{kip} 1}$ was not apparently mediated by hypoxia per se, but rather mitogenic factors such as PDGF derived via hypoxia enhanced p27kip1 protein degradation. We demonstrated that the decrease of $\mathrm{p} 27^{\mathrm{kip} 1}$ expression during hypoxia was post-transcriptional regulation from the results of RT-PCR and western blot analysis. We hypothesized that the discrepancy between the results of p27kip 1 protein expression and protein stability during hypoxia may be explained by the effect of CHX which could suppress the protein expression of the hypoxic signal transduction including hypoxia-induced growth factors, such as PDGF. Our results that PDGF decreased the stability of p27kip1 is consistent with our hypothesis, and we believe that these results are consistent with conclusion that $227^{\text {kip } 1}$ downregulation mediates hypoxia-induced HPASMC proliferation. The suppressive effect of PDGF on p27kip 1 expression has been demonstrated using rat aortic vascular smooth muscle cells [37] and in human saphenous vein smooth muscle cells [38], and oncogenic Ras induces cell cycle progression and shortens the half-life of $\mathrm{p} 27^{\mathrm{kip} 1}$ protein [39]. Since both Ras and PDGF activate mitogen-activated protein kinase (MAPK), we believe that MAPK activated through growth factors derived from hypoxia and HIF- $1 \alpha$ enhanced the degradation induced by hypoxia.

Our results showed that HPASMC incubated with BPS were arrested at the $G_{0 / 1}$ phase even under hypoxia, with p27kip1 elevation being associated with increased intracellular cAMP expression, which was not affected by the oxygen concentration. These results indicated that the BPScAMP pathway functioned even under hypoxic conditions and that $\mathrm{p} 27^{\mathrm{kip} 1}$ elevation might be a consequence of BPSinduced intracellular cAMP elevation. To confirm this hypothesis, we investigated the effects of the CAMP analogue 8-Br-cAMP on $27^{\text {kip } 1}$ expression and of BPS on DNA synthesis in p27kip1 gene knockdown HPASMC. The effects of 8-Br-cAMP and BPS on p27kip1 expression were similar and p27kip1-dependent regulation of proliferation was confirmed in the p27 kip1 knockdown cells. Overexpression of $\mathrm{p} 27^{\mathrm{kip} 1}$ in rat PASMC decreased thymidine uptake and cellular proliferation while p $27^{\text {kip } 1}$ knock-out PASMC from mouse had increased cellular proliferation compared with p27kip ${ }^{1}$ wild-type PASMC [22]. As well, Yu et al. demonstrated that hypoxia decreased p $27^{\mathrm{kip} 1}$ expression in the lung and the anti-proliferative effects of heparin during hypoxia were absent in p2 $7^{\text {kip } 1}$ knock-out mouse compared with p27kip1 wild-type mouse $[8,23]$. Using p27kip1 siRNA, we demonstrated that the anti-proliferative effects of BPS during hypoxia were lessened in the decrease of p27kip 1 . Therefore, we consider that our results from $27^{\mathrm{kip} 1}$ siRNA experiments are consistent with the published results, and we believe that our results demonstrate the importance of p27kip1 in the hypoxic regulation of PASMC proliferation and hypoxia-induced pulmonary hypertension and remodeling, which would add an important additional advancement in this field.

We also found that BPS and 8-Br-cAMP suppressed p27kip1 mRNA degradation under both normoxic and hypoxic conditions. Although cAMP regulates the expression of several genes, and the control of the mRNA degradation rate by cAMP is also an important regulatory mechanism of gene expression [40-42], the mechanisms responsible for cAMP-regulated mRNA stability are not as well understood as those of transcriptional regulation. Recent findings have suggested that $\mathrm{p} 27^{\mathrm{kip} 1} \mathrm{mRNA}$ stability is controlled by interactions between MAPK-dependent regulation [43] and Rho-dependent translation [44]. In addition, CAMP induces cell relaxation through Rho GTPase activation $[45,46]$, which might be an important target of hypoxic pulmonary vascular remodeling $[47,48]$. These reports imply that the Rho and MAPK interaction contributes to p27kip 1 mRNA stability during exposure to agents that elevate cAMP and hypoxia. Therefore, to clarify the detailed mechanisms of hypoxia and CAMP with respect to $\mathrm{p} 27^{\mathrm{kip} 1}$ expression, additional studies are 
required to explain the relationship between cAMP and Rho.

\section{Conclusion}

In summary, we found that BPS and hypoxia play critical roles in HPASMC growth through p27kip1-cAMP and hypoxia-induced pathways. We believe that clarification of the precise mechanisms of pulmonary smooth muscle proliferation will lead to improved therapeutic strategies that targets hypoxic pulmonary hypertension and remodelling of the pulmonary circulation.

\section{Competing interests}

The author(s) declare that they have no competing interests.

\section{Authors' contributions}

MK carried out the laboratory measurement and data analysis.

SM conceived the study idea and participated in the laboratory measurement and drafted the manuscript.

YD, SA, and IM participated in the design of the study.

TI supervised the study and was involved in the manuscript writing.

All authors read and approved the final manuscript.

\section{Acknowledgements}

This work was supported by grants from the Ministry of Education and Sciences of Japan (No. 16590743, 16406026, and 17790529).

\section{References}

I. Jeffery TK, Wanstall JC: Pulmonary vascular remodelling in hypoxic rats: effects of amlodipine, alone and with perindopril. Eur J Pharmacol 200I, 4I6(I-2): I23-3I.

2. Rabinovitch M, Gamble W, Nadas AS, Miettinen OS, Reid L: Rat pulmonary circulation after chronic hypoxia: hemodynamic and structural features. Am J Physiol 1979, 236(6):H8I8-27.

3. Rabinovitch M, Konstam MA, Gamble WJ, Papanicolaou N, Aronovitz $M$, Treves S, Reid L: Changes in pulmonary blood flow affect vascular response to chronic hypoxia in rats. Circ Res 1983, 52(4):432-4I.

4. Biernacki W, Flenley DC, Muir AL, MacNee W: Pulmonary hypertension and right ventricular function in patients with COPD. Chest 1988, 94(6): I 169-75.

5. Part One MacNee W: Pathophysiology of cor pulmonale in chronic obstructive pulmonary disease. Am J Respir Crit Care Med 1994, I 50(3):833-52.

6. Semmens M, Reid L: Pulmonary arterial muscularity and right ventricular hypertrophy in chronic bronchitis and emphysema. BrJ Dis Ches 1974, 68:253-63.

7. Yu AY, Shimoda LA, lyer NV, Huso DL, Sun X, McWilliams R, Beaty T, Sham JS, Wiener CM, Sylvester JT, Semenza GL: Impaired physiological responses to chronic hypoxia in mice partially deficient for hypoxia-inducible factor Ialpha. J Clin Invest 1999, 103(5):691-6.

8. Yu L, Quinn DA, Garg HG, Hales CA: Cyclin-dependent kinase inhibitor p27kipl, but not p2IWAFI/CipI, is required for inhibition of hypoxia-induced pulmonary hypertension and remodeling by heparin in mice. Circ Res 2005, 97(9):937-45.
9. Cooper AL, Beasley D: Hypoxia stimulates proliferation and interleukin-Ialpha production in human vascular smooth muscle cells. Am J Physiol 1999, 277(4 Pt 2):HI326-37.

10. Frid MG, Aldashev AA, Dempsey EC, Stenmark KR: Smooth muscle cells isolated from discrete compartments of the mature vascular media exhibit unique phenotypes and distinct growth capabilities. Circ Res 1997, 8 I(6):940-52.

II. Lu SY, Wang DS, Zhu MZ, Zhang QH, Hu YZ, Pei JM: Inhibition of hypoxia-induced proliferation and collagen synthesis by vasonatrin peptide in cultured rat pulmonary artery smooth muscle cells. Life Sci 2005, 77(I):28-38.

12. Schultz K, Fanburg BL, Beasley D: Hypoxia and hypoxia-inducible facter-I $\alpha$ promote growth facter-induced proliferation of human vascular smooth muscle cells. Am J Physiol Heart Circ Physiol 2006, 290: $\mathrm{H} 2528-\mathrm{H} 2534$.

13. Badesch DB, McLaughlin VV, Delcroix M, Vizza CD, Olschewski H, Sitbon O, Barst RJ: Prostanoid therapy for pulmonary arterial hypertension. J Am Coll Cardiol 2004, 43 (I 2 Suppl S):56S-6IS.

14. Clapp LH, Finney P, Turcato S, Tran S, Rubin LJ, Tinker A: Differential effects of stable prostacyclin analogs on smooth muscle proliferation and cyclic AMP generation in human pulmonary artery. Am J Respir Cell Mol Biol 2002, 26(2):194-201.

15. Geraci MW, Gao B, Shepherd DC, Moore MD, Westcott JY, Fagan KA, Alger LA, Tuder RM, Voelkel NF: Pulmonary prostacyclin synthase overexpression in transgenic mice protects against development of hypoxic pulmonary hypertension. J Clin Invest 1999, 103(II):1509-15.

16. Nishio S, Kurumatani H: Pharmacological and clinical properties of beraprost sodium, orally active prostacyclin analogue. Nippon Yakurigaku Zasshi 200I, I I 7(2): I23-30.

17. Galie N, Humbert M, Vachiery JL, Vizza CD, KneussI M, Manes A, Sitbon O, Torbicki A, Delcroix M, Naeije R, Hoeper M, Chaouat A, Morand S, Besse B, Simonneau G, Arterial Pulmonary Hypertension and Beraprost European (ALPHABET) Study Group: Effects of beraprost sodium, an oral prostacyclin analogue, in patients with pulmonary arterial hypertension: a randomized, double-blind, placebo-controlled trial. J Am Coll Cardiol 2002, 39(9): 1496-502.

18. Lievre M, Morand S, Besse B, Fiessinger JN, Boissel JP: Oral Beraprost sodium, a prostaglandin 12 analogue, for intermittent claudication: a double-blind, randomized, multicenter controlled trial. Circulation 2000, 102(4):426-3I.

19. Kainoh M, Maruyama I, Nishio S, Nakadate T: Enhancement by beraprost sodium, a stable analogue of prostacyclin, in thrombomodulin expression on membrane surface of cultured vascular endothelial cells via increase in cyclic AMP level. Biochem Pharmacol I991, 4 I (8): I I 35-40.

20. Hatakeyama $M$, Weinberg RA: The role of $\mathbf{R B}$ in cell cycle control. Prog Cell Cycle Res 1995, 1:9-19.

21. Fasciano S, Patel RC, Handy I, Patel CV: Regulation of vascular smooth muscle proliferation by heparin: inhibition of cyclindependent kinase 2 activity by p27kipl. J Biol Chem 2005, 280(16): 15682-9.

22. Fouty BW, Grimison B, Fagan KA, Le Cras TD, Harral JW, HoedtMiller M, Sclafani RA, Rodman DM: p27kipl is important in modulating pulmonary artery smooth muscle cell proliferation. Am J Respir Cell Mol Biol 200I, 25(5):652-8.

23. Yu L, Quinn DA, Garg HG, Hales CA: Gene expression of cyclindependent kinase inhibitors and effect of heparin on their expression in mice with hypoxia-induced pulmonary hypertension. Biochem Biophys Res Commun 2006, 345(4): 1565-72.

24. Ii M, Hoshiga M, Fukui R, Negoro N, Nakakoji T, Nishiguchi F, Kohbayashi $E$, Ishihara $T$, Hanafusa $T$ : Beraprost sodium regulates cell cycle in vascular smooth muscle cells through cAMP signaling by preventing down-regulation of p27kipl. Cardiovasc Res 200I, 52(3):500-8.

25. Gardner LB, Li Q, Park MS, Flanagan WM, Semenza GL, Dang CV: Hypoxia inhibits $G_{1} / S$ transition through regulation of p27 expression. J Biol Chem 200I, 276(I I):7919-26.

26. Graff $P$, Amellem O, Seim J, Stokke T, Pettersen EO: The role of p27 in controlling the oxygen-dependent checkpoint of mammalian cells in late GI. Anticancer Res 2005, 25(3B):2259-67.

27. Wang G, Reisdorph R, Clark RE Jr, Miskimins R, Lindahl R, Miskimins WK: Cyclin dependent kinase inhibitor $\mathrm{p} 27^{\mathrm{kipl}}$ is upregulated 
by hypoxia via an ARNT dependent pathway. I Cell Biochem 2003, 90(3):548-60.

28. Mizuno S, Kadowaki M, Demura Y, Ameshima S, Miyamori I, Ishizaki $\mathrm{T}$ : p42/44 Mitogen-activated protein kinase regulated by $\mathrm{p53}$ and nitric oxide in human pulmonary arterial smooth muscle cells. Am J Respir Cell Mol Biol 2004, 3 I (2): I84-92.

29. Fukuchi K, Tomoyasu S, Watanabe H, Tsuruoka N, Gomi K: G, accumulation caused by iron deprivation with deferoxamine does not accompany change of pRB status in ML-I cells. Biochim Biophys Acta 1997, 1357(3):297-305.

30. Cogo A, Napolitano G, Michoud MC, Barbon DR, Ward M, Martin JG: Effects of hypoxia on rat airway smooth muscle cell proliferation. J Appl Physiol 2003, 94(4): I403-9.

31. Krick S, Hanze J, Eul B, Savai R, Seay U, Grimminger F, Lohmeyer J, Klepetko W, Seeger W, Rose F: Hypoxia-driven proliferation of human pulmonary artery fibroblasts: cross-talk between HIF-I alpha and an autocrine angiotensin system. FASEB J 2005, I 9(7):857-9.

32. Norman JT, Clark IM, Garcia PL: Hypoxia promotes fibrogenesis in human renal fibroblasts. Kidney Int 2000, 58(6):235I-66.

33. Sahai A, Mei C, Pattison TA, Tannen RL: Chronic hypoxia induces proliferation of cultured mesangial cells: role of calcium and protein kinase C. Am J Physiol 1997, 273(6 Pt 2):F954-60.

34. Eto I: Nutritional and chemopreventive anti-cancer agents up-regulate expression of p27kipl, a cyclin-dependent kinase inhibitor, in mouse JB6 epidermal and human MCF7, MDAMB-32I and AU565 breast cancer cells. Cancer Cell Int 2006, 6:20.

35. Loda M, Cukor B, Tam SW, Lavin P, Fiorentino M, Draetta GF, Jessup JM, Pagano M: Increased proteasome-dependent degradation of the cyclin-dependent kinase inhibitor p27 in aggressive colorectal carcinomas. Nat Med 1997, 3(2):231-4.

36. Philipp-Staheli J, Kim KH, Liggitt D, Gurley KE, Longton G, Kemp C]: Distinct roles for $\mathrm{p} 53, \mathrm{p} 27^{\mathrm{kipl}}$, and $\mathrm{p} 2 \mathrm{ICipl}$ during tumor development. Oncogene 2004, 23(4):905-13.

37. Servant MJ, Coulombe P, Turgeon B, Meloche S: Differential regulation of p27kipl expression by mitogenic and hypertrophic factors: Involvement of transcriptional and posttranscriptional mechanisms. J Cell Biol 2000, I 48(3):543-56.

38. Marra DE, Simoncini T, Liao JK: Inhibition of vascular smooth muscle cell proliferation by sodium salicylate mediated by upregulation of p2IWafl and p27kipl. Circulation 2000, I02(17):2124-30.

39. Kawada M, Yamagoe S, Murakami Y, Suzuki K, Mizuno S, Uehara Y: Induction of p27kipl degradation and anchorage independence by Ras through the MAP kinase signaling pathway. Oncogene 1997, I5(6):629-37.

40. Dong Y, Aronsson M, Gustafsson JA, Okret S: The mechanism of cAMP-induced glucocorticoid receptor expression. Correlation to cellular glucocorticoid response. J Biol Chem 1989, 264(23): | 3679-83.

41. Jungmann RA, Kelley DC, Miles MF, Milkowski DM: Cyclic AMP regulation of lactate dehydrogenase. Isoproterenol and N6,02-dibutyryl cyclic amp increase the rate of transcription and change the stability of lactate dehydrogenase a subunit messenger RNA in rat C6 glioma cells. J Biol Chem 1983, 258(8):5312-8.

42. Sakaue M, Hoffman BB: CAMP regulates transcription of the alpha 2A adrenergic receptor gene in HT-29 cells. J Biol Chem | 99|, 266(9):5743-9.

43. Sakakibara K, Kubota K, Worku B, Ryer EJ, Miller JP, Koff A, Kent KC, Liu B: PDGF-BB regulates p27 expression through ERKdependent RNA turn-over in vascular smooth muscle cells. J Biol Chem 2005, 280(27):25470-7.

44. Vidal A, Millard SS, Miller JP, Koff A: Rho activity can alter the translation of p27 mRNA and is important for RasVI2induced transformation in a manner dependent on p27 status. J Biol Chem 2002, 277(19): 16433-40.

45. Dong JM, Leung T, Manser E, Lim L: CAMP-induced morphological changes are counteracted by the activated RhoA small GTPase and the Rho kinase ROKalpha. J Biol Chem 1998, 273(35):22554-62.

46. Laufs U, Marra D, Node K, Liao JK: 3-Hydroxy-3-methylglutarylCoA reductase inhibitors attenuate vascular smooth muscle proliferation by preventing rho GTPase-induced down-regulation of p27kipl. J Biol Chem 1999, 274(3 I):21926-3I.
47. Fagan KA, Oka M, Bauer NR, Gebb SA, Ivy DD, Morris KG, McMurtry IF: Attenuation of acute hypoxic pulmonary vasoconstriction and hypoxic pulmonary hypertension in mice by inhibition of Rho-kinase. Am J Physiol Lung Cell Mol Physiol 2004, 287(4):L656-64.

48. Hyvelin JM, Howell K, Nichol A, Costello CM, Preston RJ, McLoughlin $\mathrm{P}$ : Inhibition of Rho-kinase attenuates hypoxia-induced angiogenesis in the pulmonary circulation. Circ Res 2005, 97(2): $|85-9|$.
Publish with Bio Med Central and every scientist can read your work free of charge

"BioMed Central will be the most significant development for disseminating the results of biomedical research in our lifetime. "

Sir Paul Nurse, Cancer Research UK

Your research papers will be:

- available free of charge to the entire biomedical community

- peer reviewed and published immediately upon acceptance

- cited in PubMed and archived on PubMed Central

- yours - you keep the copyright

Submit your manuscript here:

http://www.biomedcentral.com/info/publishing_adv.asp
BiolMedcentral 